\title{
The initiation of French PhD students into the international research discourse community
}

Susan Birch-Bécaas

\section{(2) OpenEdition}

1 Journals

\section{Electronic version}

URL: http://journals.openedition.org/asp/431

DOI: $10.4000 /$ asp. 431

ISBN: 978-2-8218-0406-7

ISSN: 2108-6354

\section{Publisher}

Groupe d'étude et de recherche en anglais de spécialité

\section{Printed version}

Date of publication: 1 November 2008

Number of pages: 185-196

ISSN: 1246-8185

\section{Electronic reference}

Susan Birch-Bécaas, "The initiation of French PhD students into the international research discourse community », ASp [Online], 53-54 | 2008, Online since 01 November 2011, connection on 20 April 2019 URL : http://journals.openedition.org/asp/431 ; DOI : 10.4000/asp.431

This text was automatically generated on 20 April 2019.

Tous droits réservés 


\title{
The initiation of French PhD students into the international research discourse community
}

\author{
Susan Birch-Bécaas
}

\section{Introduction}

1 Over the last twenty to thirty years, studies on the sociology of science and ethnographic observations of research teams have led to descriptions of the organisation of these discourse communities, the genres used, the relationships between the different actors and the sociological construction of science as reflected in the publication process (Gilbert \& Mulkay 1984; Myers 1985; Latour \& Woolgar 1988; Swales 1990). It is important for the ESP practitioner to have first-hand knowledge of this research community to better understand the needs of doctoral students who are trying to enter the community and to prepare relevant materials for them. As Woodward-Kron (2004: 140) points out:

[...] without adequate means of conceptualising a discourse community, academic writing teachers also risk making connections and generalisations about student writing that may be inaccurate and misleading for specific disciplinary contexts.

In the past, many studies have looked at the difficulties that experienced researchers have in getting their work published when they are non-native speakers of English (NNSE) (St John 1987; Parkhurst 1990; Swales 1990). Studies of student writing have often focused on undergraduate tasks. Recently though, ESP research has investigated the problems inexperienced or novice researchers have in contributing to their discourse community. However, many of these studies report on ESL or EFL students working in an English-speaking academic environment with a native speaker of English supervisor (Belcher 1994; Berkenkotter 1991; Blakeslee 1997; Shaw 1991). According to Li, "little attention, if any, has been given to novices as contributors of new knowledge in disciplines" (Li 2006a: 160). She studies the case of a Chinese doctoral student of computer science contributing to knowledge construction by seeking publication in an 
international journal. Belcher has also recently voiced concerns about "off-network" scholars and their participation in mainstream anglophone journals and in the "global research conversation" (Belcher 2007: 1). To our knowledge, little is known about the French context although publishing in international journals is obviously a central issue for French PhD students who very rarely publish in French and are most often expected to have published at least two articles in international journals by the time they complete their PhDs. Thus, for the students, their supervisors and institutions the "sociopolitical implications of the publication process" (Li 2006b: 457) are great.

3 The aim of this study is therefore to investigate the difficulties faced by French doctoral students working with French supervisors. To what extent are these NNSE students, working "on the periphery" with NNSE supervisors, at a real disadvantage? How do these students acquire genre knowledge and learn to write for their community? What is the role played by the supervisor in a non-anglophone context? Allison et al. (1998: 199) paint a negative picture when they say that

not all supervisors have the knowledge and skills needed to identify exactly what it is that needs to be done in order to improve the comprehensibility of a given piece of writing. The problem is compounded when the supervisors are themselves second language speakers of the language in question.

4 However working with a NSE supervisor may not always be an advantage. Krase (2007) describes a dysfunctional relationship between an ESL graduate student and a NSE supervisor. Cultural problems and different expectations of the relationship (in this case, the student's desire for a more directive mentoring approach and the supervisor's more egalitarian, autonomous view of the relationship) can lead to poor communication.

Studies at British and American universities have reported on both successful and unsuccessful student-supervisor relationships. Berkenkotter et al. (1991) studied a doctoral student's draft introductions for the first year and a half of the PhD and noted the student's progressive socialisation into the research community. Belcher (1994) reports on three relationships between students and advisors which were not all successful. Blakeslee (1997) discusses a mentoring relationship in physics, analysing drafts and review meetings. She recommends greater support, more explicit guidance but also greater autonomy for students. She discusses how rhetorical knowledge is passed on from experienced scientists to novices and how authority is gradually conferred upon them.

Although such assumptions lead us to believe that mentoring by experienced practitioners in a scientific discipline is important for newcomers trying to learn the discipline's rhetoric, we still need micro-level analyses of how such processes work in science, and other advanced academic contexts and of what makes them more or less effective.

Such analyses can help us to understand better how newcomers to scientific or professional domains acquire the authority they need to be conventional and to gain acceptance in their communities while they struggle to establish their own authority by making original contributions to their fields. (Blakeslee 1997: 127)

In his study, Flowerdew (2000) studied the problems faced by a Hong Kong Chinese L1 scholar returning home from doctoral study in the US. He underlines the difficulty that a non-anglophone researcher working in a non-anglophone country may have seeking international publication in English. Gosden (1995) analysed texts and interpreted commentary to show how novice and expert writers interact at the Institute of Technology in Tokyo. He details changes made to drafts and asks the following question 
"The many unwritten 'rules of the game' of academic discourse manifest themselves textually in a multitude of subtle ways - how do these come to be appreciated and appropriately imitated by novices?" (Gosden 1995: 39)

The present study thus follows not fully-fledged but novice researchers working not with NSE but French supervisors. The study is based on two case studies with data collected from structured interviews with two PhD students and their supervisors. The objective was to examine the role played by the supervisor in the student's gradual enculturation into the international community, the priority given to certain genres by both students and their supervisors, the composing processes of the students and their integration into the discourse community. The results suggest that, even in this non-anglophone context, the student-supervisor relationship is an important factor in the acquisition of genre knowledge and the drafting of articles, enabling students to gradually become part of their discourse community. As ESP practitioners, we can help to reinforce the genre knowledge which is acquired from the supervisor and from exposure to the research community in writing courses for doctoral students.

The theory of "Legitimate Peripheral Participation" (Lave \& Wenger 1991) served as the framework for this study; it is outlined in the next section. The data from the interviews are then presented and compared with the findings of the other studies mentioned earlier. Finally, applications for course design are drawn from the information gained.

\section{Legitimate Peripheral Participation}

Like Belcher (1994), Blakeslee (1997) and Flowerdew (2000) in their studies, I have described the relationship between the PhD students and their supervisors in terms of "legitimate peripheral participation"(LPP), which is "the process by which newcomers become part of a community of practice" (Lave \& Wenger 1991: 29). This process of "situated learning" is seen as an apprenticeship. In order to learn, the apprentice needs to gain access to the community and to participate with experts. For a PhD student, for example, access to the community of experts may be aided by the reputation of the supervisor, the co-authoring of an article, being encouraged to attend a conference. Gradually the novice is able to increase his participation until he too is considered to be an expert in his field.

10 The novices are legitimate in that they have their place in the community which consists of "apprentices, young masters with apprentices and masters some of whose apprentices have themselves become masters" (Lave \& Wenger 1991: 56). Their participation is peripheral in that, although they have access to the community through their supervisor, they do not play a full role. In the case of a PhD student, he or she may for example attend a conference but just present a poster session, they read articles but may not yet have published themselves. Gradually they will move towards full participation. Lave and Wenger stress the fact that learning cannot take place by observation. For the novice, LPP is "more than an observational lookout post: it crucially involves participation as a way of learning - of both absorbing and being absorbed in - the 'culture of practice'." (Lave \& Wenger 1991: 95) Learning to publish means drafting, re-drafting, accepting criticism, integrating comments, restructuring, modifying claims and this cannot be learnt if the supervisor writes the article for the student. The PhD student will also take part in meetings in the laboratory, give progress reports, seminars for outside members, attend 
conferences, and possibly give popularised accounts of his work. By observing the supervisor, the student will come to understand the relationships between the different members of his discourse community, participate in the various communicative events and gain knowledge of specific genres. He will learn

who is involved, what they do; what everyday life is like; how masters talk, walk, work and generally conduct their lives; how people who are not part of the community of practice interact with it; what other learners are doing; and what learners need to become full practitioners. (Lave \& Wenger 1991: 95)

With time, the novice's contributions gain in importance. The novice is judged by the community and he is able to see how his work is judged. A PhD student will soon realise which journal he can submit to, will learn from the feedback given by reviewers and ultimately will see whether his work is accepted or rejected by the community. Soon the student will have enough knowledge of the community and its discourse to be able to fit in but he must also contribute something new to that community in order to participate more fully. Lave and Wenger point out that "granting legitimate participation to newcomers with their own viewpoints introduces into any community of practice all the tensions of the continuity-displacement contradiction" (1991: 116). However, it seems that the changes would be minimal as acceptance into the community normally means adherence to the established beliefs and conventions. As Swales (1991) points out in his definition of a discourse community, once part of the community the members are working towards common goals. Thus the community is renewed but may not be greatly modified. This rejoins Kuhn's definition of a scientific community: "To an extent unparalleled in most other fields, they have undergone similar educations and professional initiations; in the process they have absorbed the same technical literature and drawn many of the same lessons from it" (1970: 177).

\section{Two case studies}

\subsection{Background}

12 I contacted students who were attending a weekly writing workshop course for graduate students and researchers at the university and set up interviews with two of the students. Data was collected during a structured interview, which was recorded. The students were asked about their linguistic background, life in the laboratory, their experience of publishing in English, the different stages and actors involved in drafting, the role of the supervisor, the difficulties they had, and their expectations of writing courses. The students' supervisors were then contacted and interviewed. Pseudonyms will be used here when referring to the students and their supervisors.

Sophie is a second-year PhD student working in a CNRS ${ }^{1}$ laboratory at Victor-Segalen University Bordeaux 2. Her team works on the cell's perception of and responses to its environment. Sophie had had a few English classes during her first two years at university and since then she had had no further courses but had needed to read articles in English for her studies at Master's level. She had found this task difficult as she had had no training in reading skills for scientific articles. On beginning to work in the research laboratory she felt inhibited and handicapped by her lack of English. The Hong Kong Chinese scholars in Flowerdew's (1999) study reported too that they felt they had less facility of expression and took longer to write. They also cited a less rich vocabulary, 
problems of $\mathrm{L} 1$ interference, difficulty making claims and problems writing introductions and discussions. During the first year of her PhD, Sophie followed an English course in oral communication skills and this helped her gain confidence with spoken English. This year she was following the writing course as she was about to begin publishing. Her supervisor had a good level of English as he had spent two years in Boston on a postdoctoral position. He had no difficulty publishing in English, wrote directly in English and no longer used the services of a NS corrector.

The second student interviewed, Paul, is a third-year PhD student in oenology working on defects in aroma caused by fungi. He too had had no English for three years at university, just reading articles for his Master's course. He had chosen to follow the writing course this year as publishing in English was now a priority for him. Paul's supervisor however was less at ease in English than Sophie's. His spoken English has improved as he frequently has to explain his work to lay people visiting the laboratory. ${ }^{2}$ When drafting articles he prefers to write in French first, then translate and his work is always re-read by a NS corrector.

\subsection{The relationship between the student and the supervisor}

Sophie's supervisor takes his role very seriously and talks of his "duty to train". ${ }^{3}$ However he does not feel that his role is just to teach students to write articles or to help them publish. He talks about the need to "structure their scientific thought". This is confirmed by Sophie "my supervisor really wants to pass on a lot of things to me, not only from a strictly scientific point of view but also what I would call 'para-scientific'. Writing articles is part of our job". As Campbell puts it

[...] it becomes clear that there is much more to learning science than just learning the particular science, and that the primary source of this complementary learning is the individual supervisor. (2003: 902)

Sophie feels that her theoretical courses have not prepared her for the profession of researcher and life in the laboratory and so she is most at ease with the benchwork. There are other sources of learning and feedback though apart from the supervisor himself. Weekly meetings in the laboratory where one member of the team reports on his work give the students the opportunity to get suggestions and ideas from other members of the team. Sophie's supervisor says it is important for the students to face others and to be able to accept criticism. Shaw's study of overseas students at Newcastle University showed that discussions with fellow students were "a major instrument of acculturation" (1991: 189). Parkhurst's study (1990) also showed that for native speakers feedback on their work from more experienced colleagues was an important factor especially for the writing process.

Paul's supervisor saw his role in a very similar light - helping when necessary but gradually taking support away to give more autonomy to the student. Blakeslee (1997) describes how situated learning theorists use the notion of "scaffolding" to describe how experts support novices as they begin to participate in the community's activities and then gradually withdraw the support so they gain in autonomy. 


\subsection{Priorities for French $\mathrm{PhD}$ students}

18 From speaking to these two students, it became apparent that, of all the genres they were exposed to, the priority was the written research article. They were both hoping to have two articles published during their PhD years. The conference paper would seem to take second place for these students. Paul saw the advantage of making his results available rapidly and having contact with a wider audience (especially as there is another team working on his subject) but external factors such as funding problems mean that students do not have many opportunities to attend large, international conferences abroad. Sophie's supervisor advised first attending a francophone conference to get an idea of what it is all about and Sophie found that this had helped her understand the organisation of a conference so that she would gain more from the next experience. Attending a conference and presenting a paper would seem to be more important in the final year of their PhDs when they may get contacts for post-doctoral positions. For their careers in research the priority is to have two or three good publications. How do these students move from the reading of research articles to producing and publishing their own research? Their composing processes and the feedback they get from their supervisors are examined in the next section.

\subsection{Composing processes and drafts}

19 As I have mentioned above, the data obtained in this study suggest that an important part of LPP for doctoral students is learning to publish. Delamount and Atkinson explain that:

Doctoral students draw on the published findings of previous research. They move from being passive consumers of the literature to being producers of it. Just as they have learned that experiments do not always work, so too, they learn the rules of scholarly publishing. Publication is seen as a joint responsibility which provides the less experienced with practice and the opportunity to get their work in print. (2001: 88)

The drafting of a student's first article is a clear example of LPP. The student's contribution is peripheral in that the supervisor aids greatly in the process but by drafting and modifying the students is participating and the published article may be their first contribution to the community. They are granted access to the world of publication by the quality of the science, the quality of the draft but also by their association with an expert. It is now common for the student to be the first-named author of the article thus giving them more visibility and autonomy and greater participation in the community. The first article tends to be written together with the supervisor and the student is given more autonomy for the second article.

Sophie is in the process of writing her first article. She is writing up the Material and Methods section first as this is what she finds easiest as it is the most descriptive and factual section, closest to the benchwork. She will then discuss a plan for the introduction with her supervisor. The help given by her supervisor seems to be on the structure of the ideas, the ordering of information, situating her work within the body of literature. As she says "we discuss the structure of the article, how to introduce people to our work"; "he teaches me the strategies". In his study, Okamura found that junior and established researchers were distinguished most by "identification of audience" (Okamura 2006: 73). At a British university, Shaw found that supervisors helped with "theory and practical 
problems, suggested reading, written English and that they also criticised the organisation" (1991: 192). Sophie's supervisor insists on the importance of adapting students' writing to the readership. One of the main types of modifications he makes is to re-structure the information. As students do not have the reader awareness they need, they give too much technical detail and present the information in chronological sequence instead of choosing to highlight certain sections "they find it hard to break away from the bench". In Blakeslee's study of a mentoring relationship in physics, analysis of the drafts showed that the student had written a very detailed Material and Methods section which "reflected his greater familiarity with the technical aspects of his work than with the rhetorical skills he needed to present that work effectively to other scientists". (1997: 138)

A second type of modification concerns the importance of the claims made in the article. Sophie's supervisor feels that students are often too cautious, "very intellectually honest" sometimes they do not know how far to go and he talks of their "fear of taking a stance", "when writing up we allow ourselves to do certain things". Gradually, as Delamount and Atkinson put it, "they learn to write public accounts of their investigations which omit the uncertainties, contingencies and personal craft skills." (2001: 88) Belcher also reports on three case studies of students and advisors and found the most effective relationship to be one that was collaborative, supportive and encouraged "risk-taking entailed in challenging and attempting to contribute to the established knowledge of a community." (1994: 32) The students must contribute to the literature while at the same, being novices in the community, showing caution and not taking too strong a stance.

The advice given by Sophie's supervisor on the rhetoric of science, the language of claims and information structure bears witness to the importance of this novice-expert relationship. However, the supervisor concludes by saying "I don't feel sufficiently at ease to teach people how to write". The supervisor tries to maintain a balance between the learning process, a succession of drafts, which take time and the temptation to re-write sections as the ultimate aim is to get the article published. For him the style of the writing is 'imitative' as both he and the student are influenced by the expressions of the articles they have read. Shaw also found that "By far the most frequent strategy used by these interviewees to improve their command of the subject register is conscious examination of their source texts." (1991: 195)

The other student Paul, is more advanced in the publication game as he published his first article last year (in the second year of his PhD). He writes directly in English (as most students and researchers seem to) as this is easier for him after reading articles in English. This is confirmed by Parkhurst who found that nonnative speakers emphasized the importance of extensive reading. "The majority of nonnative scientists reported having taught themselves to write well by reading extensively and then imitating the style of what they had read" (1990: 175). For Paul the most difficult parts of the article to write are of course the introduction and the discussion. The ideas are discussed with the supervisor and the revision sessions lead to a series of drafts. Paul's supervisor is anxious not to impose his ideas; the priority is that Paul should write and then discussions can take place. Blakeslee also found that there must be a balance between guidance and appropriation "too much support and over-correction can be inhibiting" (1997: 153); he adds "mentors must let go of tasks sufficiently to give students adequate experience performing them" (1997: 154). 


\subsection{Integration in the discourse community}

Finally, the degree of integration of these students in their discourse community was analysed. It would seem that there is a difference between the second year and the final year of doctoral studies although it may also be a question of individual personality and subject.

Sophie still feels very much a student while Paul, in his third year is making the transition from student to scientist. Sophie says "I don't feel I'm a researcher". But she is finding her place in the community and feels she has progressed enormously between the first and second year, not just scientifically but what she terms "para-scientific". "You find your place in the field and feel you're progressing". She recognises the need to publish and feels she will gain greater autonomy when she has finished her $\mathrm{PhD}$ and takes up a post-doctoral position. She is learning an enormous amount from her supervisor but already perceives that there will be a transition and a change in her identity "as I gradually become more detached from him then what he has transmitted will be transferred into real autonomy". This close collaboration is confirmed by Sophie's supervisor who recognises that he has an enormous influence on his students. This confirms Belcher's study which highlighted the idea of self-replication in the relationship.

Paul feels more integrated as the subject of his thesis has become very pertinent. He has already published and is known for his work in this domain "when you look and find yourself in the database, you're not the same anymore". In the laboratory, there is still a hierarchy but outside he feels that he has peer status. After defending his thesis he feels he will be totally integrated. Paul's supervisor has also witnessed his growing maturity how he has acquired rhetorical awareness and knowledge of his community's norms and conventions.

\section{Conclusion}

This study describes two successful student-supervisor relationships. The participation of the $\mathrm{PhD}$ students in their laboratories and their discourse communities resulted in an increasing awareness of their community's norms and conventions. This knowledge was acquired not by observing but by increasing involvement and participation with expert members. The relationship between students and their supervisors was of paramount importance in the transmission of genre knowledge. Flowerdew rightly claims that:

Arguably, graduate students learn as much through the various opportunities for peripheral participation they are exposed to - working as members of research teams, interacting with their academic supervisors, submitting papers for publication, and communicating with journal editors and reviewers - as they do in the more formal, taught part of their courses. (2000: 131)

In this study the NNSE students working with NNSE supervisors were able to learn how to publish and gain acceptance. The literature shows though that these relationships can also be unsuccessful. What seems to be important is the nature of the relationship. It may be that the French supervisors in this study, having struggled themselves with the publication process and the language problems involved, are sensitive to the problems that their students may encounter. 

two unsuccessful mentoring relationships which failed as the students did not have confidence in their advisor's judgement and were not in fact suited to their community of practice. Situated learning may also be too implicit for some students. Blakeslee (1997) warns that some supervisors may lack the necessary awareness, ability or competence to convey skills and may not be effective writers themselves.

To answer Berkenkotter's question: "How much information regarding the discoursal expectations of those who teach, write and read in the sciences [...] needs to be made explicit to students in their curricula?" (1991: 212), the feedback from the students and supervisors in this study shows that, although much knowledge is acquired through participation and implicitly from the supervisor there is a real need for this genre knowledge to be formalised in writing courses to enable students to progress more quickly and to explicitly reinforce ideas they are picking up from their reading of articles and from discussions in the laboratory. For Flowerdew, writing courses are "an opportunity for bringing together apprentice professionals to share their experiences and reflect together on their ongoing LPP" (2000: 147). English courses at Master's level could focus on reading strategies for research articles and in the first years of doctoral studies priority should be given to writing up research: the structure of introductions and discussions, illustrating the moves within these sections and their linguistic realisations. Students can focus on strategies to highlight information, to indicate the significance of their work and to modulate claims. The study of genre models, analysing the rhetoric of the discourse, its phraseology and the more local language problems can be combined with a process approach of drafting, revising and getting feedback from peers. Gradually these students will become more effective and autonomous writers.

The author wishes to thank Dr. Monique Mémet for insightful comments on an earlier draft of this paper.

\section{BIBLIOGRAPHY}

Allison, D., L. Cooley, J. Lewkowicz and D. Nunan. 1998. "Dissertation writing in action: The development of a dissertation writing support program for ESL graduate research students". English for Specific Purposes 17/2, 199-217.

Belcher, D. 1994. “The apprenticeship approach to advanced academic literacy: Graduate students and their mentors". English for Specific Purposes 13/1, 23-34.

Belcher, D. 2007. "Seeking acceptance in an English-only research world". Journal of Second Language Writing 16, 1-22.

Berkenkotter, C., T. N. Huckin and J. Ackerman. 1991. "Social context and socially constructed texts: The initiation of a graduate student into a writing research community". InC. Bazerman and J. Paradis (eds.) Textual Dynamics of the Professions. Historical and Contemporary Studies of Writing in Professional Communities. Madison, WI: University of Wisconsin Press, 191-215. 
Blakeslee, A. M. 1997. “Activity, context, interaction, and authority: Learning to write scientific papers in situ". Journal of Business and Technical Communication 11/2, 125-169.

Burrough-Boenisch, J. 2003. "Shapers of published NNS research articles." Journal of Second Language Writing 12, 223-243.

Campbell, R. A. 2003. "Preparing the next generation of scientists: The social process of managing students". Social Studies of Science 33/6, 897-927.

Delamount S. and P. Atkinson. 2001. "Doctoring uncertainty: Mastering craft knowledge”. Social Studies of Science 31/1, 87-107.

Flowerdew, J. 1999. "Problems in writing for scholarly publication in English: The case of Hong Kong”. Journal of Second Language Writing 8/3, 243-264.

Flowerdew, J. 2000. “Discourse community, Legitimate Peripheral Participation, and the nonnative-English-speaking scholar”. TESOL Quarterly 34/1, 127-150.

Gilbert, G.N. and M. Mulkay. 1984. Opening Pandora's Box. A Sociological Analysis of Scientist's Dicourse. Cambridge: Cambridge University Press.

Gosden, H. 1995. "Success in research article writing and revision: A social-constructionist perspective". English for Specific Purposes 14/1, 37-57.

Kaplan, R. and W. Grabe. 1991. “The fiction in science writing”. In Hartmut Schröder (ed.) SubjectOrientated Texts. Languages for Special Purposes and Text Theory. Berlin: Walter de Gruyter.

Krase, E. 2007. "Maybe the communication between us was not enough": Inside a dysfunctional advisor/L2 advisee relationship". Journal of English for Academic Purposes 6, 55-70.

Kuhn, T. S. 1970. The Structure of Scientific Revolutions. Chicago: University of Chicago Press.

Latour, B. and S. Woolgar. 1988. La vie de laboratoire. La production des faits scientifiques. Paris: Éditions de la Découverte.

Lave, J. and E. Wenger. 1991. Situated Learning: Legitimate Peripheral Participation. Cambridge: Cambridge University Press.

Li, Y. 2006a. "Negotiating knowledge contribution to multiple discourse communities: A doctoral student of computer science writing for publication". Journal of Second Language Writing 15, 159-178.

Li, Y. 2006b. "A doctoral student of physics writing for publication: A sociopolitically-orientated case study". English for Specific Purposes 25, 456-478.

Myers, G. 1985. “Text as knowledge claims: The social construction of two biology articles”. Social Studies of Science 15, 593-630.

Okamura, A. 2006. "Two types of strategies used by Japanese scientists, when writing research articles in English". System 34, 68-79.

Parkhurst, C. 1990. "The composition process of science writers". English for Specific Purposes 9, 169-179.

Shaw, P., 1991. "Science research students' composing processes". English for Specific Purposes 10, 189-206.

Swales, J. 1990. Genre Analysis: English in Academic and Research Settings. Cambridge: Cambridge University Press. 
Woodward-Kron, R. 2004. "Discourse communities and writing apprenticeship: An investigation of these concepts in undergraduate Education students' writing". Journal of English for Academic Purposes 3, 139-161.

\section{NOTES}

1. Centre national de la recherche scientifique.

2. He explained that a specificity of oenology is that the popularisation of their work is very important for people working in the wine business

3. The comments of the students and supervisors have been translated from the French.

\section{ABSTRACTS}

The aim of this study is to investigate how French PhD students are sensitised to the rhetoric of science and gradually learn how to publish and gain acceptance in the international community. The study is based on two case studies of PhD students and their supervisors. Through structured interviews the author examines the relationship between the non-native speaker of English (NNSE) student and NNSE supervisor focusing on the transmission of the conventions of the community to the student. Investigating the students' composing processes highlights the elements which are problematic for these students in the drafting of articles. The students' gradual integration into their community is described in terms of "Legitimate Peripheral Participation" (Lave \& Wenger 1991). This study suggests that, in this French context, the student-supervisor relationship is an important factor in the transmission of genre knowledge and in learning how to draft articles in English. However, the implicit nature of this relationship underlines the need for such linguistic, rhetorical and cultural conventions to be formalised in writing courses for doctoral students.

L'objectif de cette étude est d'examiner comment les doctorants français sont sensibilisés à la rhétorique de la science, comment ils apprennent à rédiger en anglais en se conformant aux attentes de leur public. L'étude se fonde sur deux études de cas de doctorants français travaillant avec des directeurs de thèse français. Grâce à des entretiens, l'auteur analyse la relation entre l'étudiant et le directeur et leur intégration dans la communauté de discours est décrite en termes de «Participation Périphérique Légitime» (Lave \& Wenger 1991). L'étude des stratégies de rédaction révèle les éléments qui posent problème lors de la rédaction. Il semblerait que cette relation entre étudiant et directeur soit un facteur important dans l'apprentissage de la rédaction. Cependant, le caractère implicite de cette relation souligne également l'importance de la mise en place de cours de rédaction scientifique en anglais pour formaliser cet apprentissage. 
INDEX

Mots-clés: anglais pour la recherche, communauté de discours, cours de rédaction scientifique, directeur de thèse, doctorant, participation périphérique légitime, stratégie de rédaction Keywords: composing process, discourse community, English for Research Purposes, legitimate peripheral participation, $\mathrm{PhD}$ student, supervisor, writing course

\section{AUTHOR}

\section{SUSAN BIRCH-BÉCAAS}

Susan Birch-Becaas is a Senior Lecturer at Université Victor Segalen, Bordeaux 2. Her research publications deal with research writing, the analysis of scientific discourse and its applications for writing courses. susan.birch@lv.u-bordeaux2.fr 